\title{
STUDY OF THE STRUCTURE AND COMPLEXATION \\ OF ORGANIC AND INORGANIC DERIVATIVES OF METALS BY MEANS OF N.M.R. SPECTROSCOPY OF HEAVY NUCLEI
}

\author{
V. S. Petrosyan and O. A. Reutov \\ Chemistry Department, Moscow State University, Moscow, USSR
}

\begin{abstract}
Data are considered about the structure and complexation of many compounds of tin and mercury, obtained by the present authors and other investigators by means of n.m.r. spectroscopy of ${ }^{119} \mathrm{Sn}$ and ${ }^{199} \mathrm{Hg}$. In the case of tin compounds important information can be derived from the values of chemical shifts

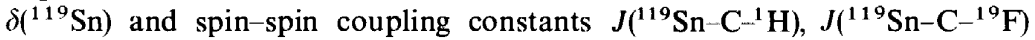
and $J\left({ }^{119} \mathrm{Sn}-{ }^{13} \mathrm{C}\right)$. Conclusions about the structure and complexation of mercury compounds are derived mainly from the spin-spin coupling constants $J\left({ }^{199} \mathrm{Hg}-\mathrm{C}-{ }^{1} \mathrm{H}\right), J\left({ }^{199} \mathrm{Hg}-\mathrm{C}-{ }^{19} \mathrm{~F}\right)$ and $J\left({ }^{199} \mathrm{Hg}{ }^{13} \mathrm{C}\right)$, though data about the $\delta\left({ }^{199} \mathrm{Hg}\right)$ are also available.
\end{abstract}

The application of n.m.r. spectroscopy to the study of organic and inorganic derivatives of metals, the isotopes of which have necessary magnetic properties, was shown to be very productive from the viewpoint of information about the behaviour of these compounds in solution. This information is very important for solving the many problems of inorganic and organometallic chemistry. One such problem is the question about the effect of solvents upon the rates and mechanisms of inorganic and organometallic compounds ${ }^{1}$.

A review about the p.m.r. spectra of different compounds of metals was published recently ${ }^{2}$. In the present work we are illustrating the possibilities of applying n.m.r. spectroscopy of heavy nuclei to the study of the structure and complexation of organic and inorganic derivatives of metals, using the data about the chemical shifts of ${ }^{119} \mathrm{Sn}$ and ${ }^{199} \mathrm{Hg}$ nuclei and their spinspin coupling constants with ${ }^{1} \mathrm{H},{ }^{13} \mathrm{C}$ and ${ }^{19} \mathrm{~F}$ for different compounds of tin and mercury.

\section{TIN COMPOUNDS}

In 1961 Burke and Lauterbur ${ }^{3}$ studied ${ }^{119}$ Sn n.m.r. spectra of eighteen organic and inorganic derivatives of tin and showed that $\delta\left({ }^{119} \mathrm{Sn}\right)$ varied by $1850 \mathrm{ppm}$ depending upon the structure of the molecules. It was assumed that such a large range of $\delta\left({ }^{119} \mathrm{Sn}\right)$ values cannot be rationalized by changes in the diamagnetic term of the ${ }^{119} \mathrm{Sn}$ screening constant, but that it merely reflects 
great sensitivity to changes in the structure of the paramagnetic term in the Ramsay equation. The unusual large solvent effect on $\delta\left({ }^{119} \mathrm{Sn}\right)$, observed at the same time, was rationalized by the authors in terms of coordination between the solute and solvent molecules.

The list of tin compounds for which the values of $\delta\left({ }^{119} \mathrm{Sn}\right)$ were reported ${ }^{4-17}$ was then greatly increased. A review on the chemical shifts of ${ }^{1{ }^{19}} \mathrm{Sn}$ has been submitted for publication ${ }^{18}$ and therefore here we will only consider some of the data; but sufficient to show that in some cases there is a good correlation between the $\delta\left({ }^{119} \mathrm{Sn}\right)$ value and the electron-withdrawing power of substituents (Table 1), but that in other cases the changes of $\delta\left({ }^{19} \mathrm{Sn}\right)$ cannot be rationalized in a simple way.

Table 1. $\delta\left({ }^{119} \mathrm{Sn}\right)$ values for $\mathrm{Me}_{3} \mathrm{SnX}$ compounds ${ }^{6,7}$

\begin{tabular}{lcc}
\hline \multicolumn{1}{c}{$\mathrm{X}$} & Solvent & $\begin{array}{c}\delta\left({ }^{119} \mathrm{Sn}\right) \\
(\mathrm{ppm})\end{array}$ \\
$\mathrm{Cl}$ & & -166 \\
$\mathrm{Br}$ & $\mathrm{CH}_{2} \mathrm{Cl}_{2}$ & -128 \\
$\mathrm{CCl}_{3}$ & Benzene & -85 \\
$\mathrm{CCl}_{2} \mathrm{H}$ & Benzene & -33 \\
$\mathrm{CClH}_{2}$ & Benzene & -4 \\
$\mathrm{Me}$ & Benzene & 0 \\
$\mathrm{Bu}$ & $\mathrm{CH}_{2} \mathrm{Cl}_{2}$ & +2 \\
$\mathrm{Ph}$ & Benzene & +30 \\
$\mathrm{CH} \mathrm{CH}_{2}$ & - & +35 \\
$\mathrm{Me}_{3} \mathrm{Sn}$ & - & +113 \\
\hline
\end{tabular}

The examples in Table 2 show that in going from $\mathrm{Me}_{4} \mathrm{Sn}$ to $\mathrm{Me}_{3} \mathrm{SnBr}$ the expected deshielding of ${ }^{119} \mathrm{Sn}$ is observed. Further progressive substitution of $\mathrm{Me}$ on $\mathrm{Br}$ leads to a strong shift of resonance to a high field. This fact can be rationalized only if we assume an increasing contribution of the (d-p) $\pi$ interactions with the increasing number of $\mathrm{Br}$ atoms.

Table 2. $\delta\left({ }^{119} \mathrm{Sn}\right)$ values for $\mathrm{Me}_{n} \mathrm{SnBr}_{4-n}(n=0-4)$ compounds ${ }^{3.6 .7}$

\begin{tabular}{llc}
\hline Compound & Solvent & $\begin{array}{c}\left.\delta{ }^{119} \mathrm{Sn}\right) \\
(\mathrm{ppm})\end{array}$ \\
\hline $\mathrm{Me}_{3} \mathrm{SnBr}$ & Benzene & -128 \\
$\mathrm{Me}_{2} \mathrm{SnBr}_{2}$ & $\mathrm{CHCl}_{3}$ & -74 \\
$\mathrm{Me}_{4} \mathrm{Sn}_{\mathrm{MeSnBr}_{3}}$ & $\mathrm{CH}_{2} \mathrm{Cl}_{2}$ & 0 \\
$\mathrm{SnBr}_{4}$ & $\mathrm{CH}_{2} \mathrm{Cl}_{2}$ & +170 \\
\hline
\end{tabular}

We will consider most carefully the spin-spin coupling constants of ${ }^{119} \mathrm{Sn}$ with ${ }^{1} \mathrm{H},{ }^{13} \mathrm{C}$ and ${ }^{19} \mathrm{~F}$ nuclei, which are widely used for the structure analysis of different $\Delta t$ inorganic compounds. First of all we will consider the influence of the nature of $\mathrm{X}$ in $\mathrm{Me}_{3} \mathrm{SnX}$ on the $J\left({ }^{119} \mathrm{Sn}-\mathrm{C}-{ }^{1} \mathrm{H}\right)$ spin-spin coupling constants (Table 3). 
Table 3. $J\left({ }^{119} \mathrm{Sn}-\mathrm{C}-{ }^{1} \mathrm{H}\right)$ values for solutions of $\mathrm{Me}_{3} \mathrm{SnX}$ in $\mathrm{CCl}_{4}{ }^{19-22}$

\begin{tabular}{lc}
\hline \multicolumn{1}{c}{$\mathrm{X}$} & $\begin{array}{c}\left.{ }^{1{ }^{19}} \mathrm{Sn} \mathrm{C-.}{ }^{1} \mathrm{H}\right) \\
(\mathrm{Hz})\end{array}$ \\
\hline $\mathrm{Me}_{3} \mathrm{Sn}$ & 48.5 \\
$\mathrm{Me}$ & 54.0 \\
$\mathrm{C}_{6} \mathrm{H}_{5}$ & 54.6 \\
$\mathrm{C}_{6} \mathrm{Cl}_{5}$ & 56.8 \\
$\mathrm{I}$ & 57.2 \\
$\mathrm{Br}$ & 57.8 \\
$\mathrm{Cl}$ & 58.1 \\
$\mathrm{C}_{6} \mathrm{~F}_{5}$ & 58.4 \\
$\mathrm{CF}_{3}$ & 58.7 \\
$\mathrm{~F}$ & 69.0 \\
\hline
\end{tabular}

It is evident from the data of Table 3 that $J\left({ }^{1{ }^{19}} \mathrm{Sn}-\mathrm{C}-{ }^{1} \mathrm{H}\right)$ increases with an increase of the electron-withdrawing power of the group $\mathrm{X}$. The up-to-date explanation of this fact is that there is a corresponding increase in the $s$ character of the $\mathrm{sp}^{3}$-hybrid orbitals of tin in the tin-carbon bonds ${ }^{23-25}$. This conclusion was first made by Holmes and Kaesz ${ }^{26}$, who supposed that the main contribution to the observed coupling constants is made by the Fermi contact term and that these coupling constants do not depend upon the $\mathrm{s}$ electron density on coupled protons and the geminal angle Sn-C-H. Nevertheless, Verdonck and Van der Kelen ${ }^{27-30}$ have shown the importance of such contributions as the spin-orbital term and the s electron density on coupled protons. On the other hand, it was shown recently that diastereotopic methyl groups ${ }^{31}$ and anisochronic methylene protons ${ }^{32}$, bonded with tin atoms in several types of the molecules, have different spin-spin coupling constants with ${ }^{119} \mathrm{Sn}$ nuclei. These facts were considered to be direct evidence for the angle dependence of $J\left({ }^{119} \mathrm{Sn} \mathrm{C}^{-1} \mathrm{H}\right)^{32}$.

Thus, in the course of the study of $J\left({ }^{119} \mathrm{Sn}-\mathrm{C}-{ }^{1} \mathrm{H}\right)$ values it is necessary to consider their dependence, not on the s-character of $\mathrm{sp}^{n}$-hybrid orbitals of tin in $\mathrm{Sn}-\mathrm{C}$ bonds, but on the relative content of s electrons in the whole fragment $\mathrm{Sn}-\mathrm{C}-\mathrm{H}$, in which coupling occurs, and on the geminal angle between the $\mathrm{Sn}-\mathrm{C}$ and $\mathrm{C}-\mathrm{H}$ bonds. As regards the spin-orbital term, it is not so important for $J\left({ }^{119} \mathrm{Sn}-\mathrm{C}-{ }^{1} \mathrm{H}\right)$, but is more important in the cases of $J\left({ }^{1{ }^{19}} \mathrm{Sn}-\mathrm{C}-{ }^{19} \mathrm{~F}\right)$ and $J\left({ }^{119} \mathrm{Sn}-{ }^{13} \mathrm{C}\right){ }^{28}$. Unfortunately the number of literature values of $J\left({ }^{119} \mathrm{Sn}-\mathrm{C}-{ }^{19} \mathrm{~F}\right)$ is small and most of them are given in Table 4.

Table 4. $J\left({ }^{119} \mathrm{Sn}-\mathrm{C}-{ }^{19} \mathrm{~F}\right)$ for several organotin compounds $\mathrm{s}^{21,33,34}$

\begin{tabular}{lcc}
\hline \multicolumn{1}{c}{ Compound } & $\begin{array}{c}J\left({ }^{119} \mathrm{Sn}-\mathrm{C}-{ }^{19} \mathrm{~F}\right) \\
(\mathrm{Hz})\end{array}$ & $\begin{array}{c}J\left({ }^{119} \mathrm{Sn} \mathrm{C}^{1} \mathrm{H}\right) \\
(\mathrm{Hz})\end{array}$ \\
\hline $\mathrm{Me}_{3} \mathrm{SnCF}_{3}$ & 293.0 & 58.7 \\
$\mathrm{Me}_{3} \mathrm{SnCF}_{2} \mathrm{CF}_{2} \mathrm{H}$ & 249.5 & 57.8 \\
$\mathrm{Me}_{3} \mathrm{SnCF}_{2} \mathrm{CFHCF}_{3}$ & 222.0 & 58.6 \\
$\mathrm{Me}_{2} \mathrm{SnH}\left(\mathrm{CF}_{2} \mathrm{CF}_{2} \mathrm{H}\right)$ & 251.0 & 62.8 \\
$\mathrm{Me}_{2} \mathrm{Sn}\left(\mathrm{CF}_{2} \mathrm{CF}_{2} \mathrm{H}\right)_{2}$ & 274.0 & 64.5 \\
\hline
\end{tabular}


It is dangerous to draw any conclusions from these constants about their correlation with the structure of the molecules, especially since their changes do not correlate with the changes of $J\left({ }^{119} \mathrm{Sn}-\mathrm{C}_{-}{ }^{1} \mathrm{H}\right)$ for these compounds.

$J\left({ }^{1 / 1} \mathrm{Sn}-{ }^{13} \mathrm{C}\right)$ spin-spin coupling constants have been studied in the last few years for several types of organotin compounds (Table 5) and in recent work by Schaeffer and Zuckermann ${ }^{40}$ they have been measured for thirteen meta- and para-substituted aryltrimethyltin compounds.

Table 5. $J\left({ }^{119} \mathrm{Sn}-{ }^{13} \mathrm{C}\right)$ values for several organotin compounds ${ }^{35}{ }^{34}$

\begin{tabular}{|c|c|c|}
\hline Compound & Solvent & $\underset{(\mathrm{H} z)}{J\left({ }^{119} \mathrm{Sn} \cdot{ }^{13} \mathrm{C}\right)}$ \\
\hline $\mathrm{Me}_{4} \mathrm{Sn}$ & $\begin{array}{l}+10 \% \text { dioxane } 35 \\
+10 \% \text { benzene } \\
36,37\end{array}$ & $\begin{array}{l}340^{35} \\
336^{36} \\
330^{37}\end{array}$ \\
\hline $\mathrm{Et}_{4} \mathrm{Sn}$ & & 321.5 \\
\hline$\left(\mathrm{CH}_{2}=\mathrm{CHCH}_{2}\right)_{4} \mathrm{Sn}$ & & 250 \\
\hline$\left(\mathrm{Me}_{3} \mathrm{Sn}\right)_{2} \mathrm{C}_{5} \mathrm{H}_{4}$ & & 340 \\
\hline $\mathrm{Me}_{3} \mathrm{SnBr}$ & $+10^{\circ}{ }_{0}$ benzene & 380 \\
\hline $\mathrm{Me}_{2} \mathrm{SnCl}_{2}$ & Acetone & 556 \\
\hline $\mathrm{MeSnBr}_{3}$ & Benzene & 640 \\
\hline
\end{tabular}

It was shown that substituents with negative $\sigma$ constants are in general associated with lower $J\left({ }^{119} \mathrm{Sn}-{ }^{13} \mathrm{C}\right)$ values than those with positive $\sigma$ constants, though the increase in the $J\left({ }^{119} \mathrm{Sn}-{ }^{13} \mathrm{C}\right)$ value with increasing $\sigma$ constant is not monotonic. At the same time $J\left({ }^{119} \mathrm{Sn}-{ }^{13} \mathrm{C}_{1}\right)$ values decrease with increasing $\sigma$ constants. These facts were rationalized ${ }^{40}$ using Bent's isovalent hybridization model ${ }^{41}$, according to which the redistribution of electrons in molecules occurs in such a way that $\mathrm{s}$ electrons of $\mathrm{sp}^{n}$-hybrid orbitals of the central atom concentrate in the bonds with the most electropositive substituents; and $\mathrm{p}$ electrons concentrate in the bonds with the most electro-negative substituents.

The conclusions about the linear dependence of $J\left({ }^{119} \mathrm{Sn}-\mathrm{C}-{ }^{1} \mathrm{H}\right)$ on the $\mathrm{s}$ character of $\mathrm{sp}^{n}$-hybrid orbitals of tin in $\mathrm{Sn}-\mathrm{C}$ bonds, drawn by Holmes and Kaesz ${ }^{26}$, in spite of the serious objections discussed above, have become very popular among scientists who have studied the complexation of organotin compounds ${ }^{20,25,42-50}$. We want to illustrate the applications of ${ }^{119} \mathrm{Sn}$ n.m.r. spectroscopy with the example of the $\mathrm{Me}_{3} \mathrm{SnX}-\mathrm{D}$ complexes, where $\mathrm{X}=\mathrm{Cl}$, $\mathrm{Br}, \mathrm{CF}_{3}$ and $\mathrm{D}=$ monodentate organic solvents, such as acetone, pyridine, dimethylformamide (DMFA), dimethylsulphoxide (DMSO) and hexamethylphosphortriamide (HMPTA). Complexes of this type were isolated as molecular crystals ${ }^{21.51}$ and according to the data of $\mathrm{x}$-ray spectroscopy ${ }^{52.53}$ they are likely to have a trigonal bipyramid structure. The electron distribution in these complexes depends upon the electron-donating ability of $\mathrm{D}$ and the electron-withdrawing power of $X^{54.55}$.

In solution there is an equilibrium between the free and complexed molecules of $\mathrm{Me}_{3} \mathrm{SnX}$. Therefore the observed $J\left({ }^{119} \mathrm{Sn}-\mathrm{C}^{-1} \mathrm{H}\right)$ spin - spin coupling constants are:

$$
J_{\mathrm{ubs}}=p_{\mathrm{A}} J_{\mathrm{A}}+p_{\mathrm{AD}} J_{\mathrm{AD}}
$$


where $p_{\mathrm{A}}$ and $p_{\mathrm{AD}}$ are the molar fractions of a free acceptor and complex, and $J_{\mathrm{A}}$ and $J_{\mathrm{AD}}$ are the $J\left({ }^{119} \mathrm{Sn}-\mathrm{C}-{ }^{1} \mathrm{H}\right)$ constants for the same molecules. The study of the concentration and temperature dependences of $J\left({ }^{119} \mathrm{Sn}-\mathrm{C}-{ }^{1} \mathrm{H}\right)$, carried out ${ }^{55}$ for several systems, enabled the $J_{\mathrm{AD}}$ and $K_{\text {eq }}$ values to be obtained for these systems (Table 6).

Table 6. $J_{\mathrm{AD}}$ and $K_{\mathrm{eq}}$ values for $\mathrm{Me}_{3} \mathrm{SnX}-\mathrm{D}$ complexes ${ }^{55}$

\begin{tabular}{cccc}
\hline $\mathrm{D}$ & $\mathrm{X}$ & $J_{\mathrm{AD}}(\mathrm{Hz})$ & $K_{\mathrm{eq}}{ }^{\dagger}\left(\mathrm{mol}^{-1}\right)$ \\
\hline Acetone & $\mathrm{Cl}$ & 66.0 & $0.8 \pm 0.1$ \\
& $\mathrm{Br}$ & 65.5 & $0.6 \pm 0.1$ \\
Pyridine & $\mathrm{Cl}$ & 68.0 & $36 \pm 3$ \\
& $\mathrm{Br}$ & 67.6 & $28 \pm 3$ \\
DMFA & $\mathrm{Cl}$ & 70.0 & $3.0 \pm 0.5$ \\
& $\mathrm{Br}$ & 69.6 & $3.1 \pm 0.3$ \\
DMSO & $\mathrm{Cl}$ & 70.1 & $2.3 \pm 0.4$ \\
& $\mathrm{Br}$ & 69.6 & $231 \pm 0.5$ \\
HMPTA & $\mathrm{Cl}$ & 71.8 & $232 \pm 9$ \\
\hline
\end{tabular}

$+K_{\mathrm{eq}}$ values were obtained at $-30 \mathrm{C}$ except for the DMSO complexes when they were measured at $-10 \mathrm{C}$.

The results of Table 6 correlate well with the data from the study of the solvent effect upon the $\delta\left({ }^{119} \mathrm{Sn}\right){ }^{6,13}$ and $J\left({ }^{119} \mathrm{Sn}-\mathrm{C}-{ }^{1} \mathrm{H}\right)$ constants ${ }^{45,46,49}$ in related systems. These results indicate the increase of the relative content of $\mathrm{s}$ electrons in the $\mathrm{Sn}-\mathrm{C}-\mathrm{H}$ fragment on passing from the free acceptor to the complex. In this case there is a good correlation between the increase of the relative content of s electrons in the $\mathrm{Sn}-\mathrm{C}-\mathrm{H}$ fragment and the growth of the relative content of p electrons in the $\mathrm{Sn}-\mathrm{Hal}$ bonds (from n.q.r. data ${ }^{54}$ ).

Of special interest from this viewpoint are our recent results ${ }^{21}$ concerning

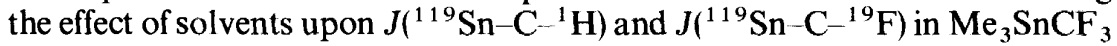
(Table 7).

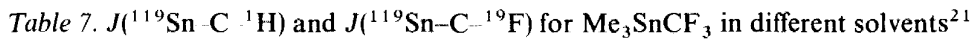

\begin{tabular}{lcc}
\hline \multicolumn{1}{c}{ Solvent } & $\begin{array}{c}J\left({ }^{119} \mathrm{Sn}-\mathrm{C}^{1} \mathrm{H}\right) \\
(\mathrm{Hz})\end{array}$ & $\begin{array}{c}J\left({ }^{119} \mathrm{Sn}-\mathrm{C}_{-}{ }^{19} \mathrm{~F}\right) \\
(\mathrm{Hz})\end{array}$ \\
\hline Cyclohexane & 58.4 & 300 \\
$\mathrm{CCl}_{+}$ & 58.7 & 293 \\
$\mathrm{Et}_{\mathrm{\gamma}} \mathrm{O}$ & 59.4 & 283 \\
$\mathrm{THF}$ & 61.9 & 235 \\
Pyridine & 62.7 & 188 \\
DMFA & 65.1 & 173 \\
DMSO & 66.4 & 144 \\
HMPTA & 68.6 & 115 \\
\hline
\end{tabular}

A comparison with the data of Table 3 shows that the $\mathrm{CF}_{3}$ group is very close to the halogens in its features, but that it is somewhat more electronwithdrawing. This allowed us to consider $\mathrm{Me}_{3} \mathrm{SnCF}_{3}$ as a more powerful acceptor of the electrons in complexation. But a comparison of the results in Tables 3, 6 and 7 shows that the variation of $J\left({ }^{119} \mathrm{Sn}-\mathrm{C}-{ }^{1} \mathrm{H}\right)$ values on 
going from the solutions in $\mathrm{CCl}_{4}$ to those in strong electron-donating solvents is far less in $\mathrm{Me}_{3} \mathrm{SnCF}_{3}(7-10 \mathrm{~Hz})$ than in $\mathrm{Me}_{3} \mathrm{SnHal}(12-14 \mathrm{~Hz})$. In our opinion, these facts are convincing evidence that it is more difficult to form complexes of electron-donating solvents with $\mathrm{Me}_{3} \mathrm{SnCF}_{3}$ than with $\mathrm{Me}_{3} \mathrm{SnHal}$. Additional evidence for this conclusion is the fact that $\mathrm{Me}_{3} \mathrm{SnHal}$ easily forms solid molecular complexes of the type $\mathrm{Me}_{3} \mathrm{SnHal}-\mathrm{D}^{5 i}$, while in the case of $\mathrm{Me}_{3} \mathrm{SnCF}_{3}$ an analogous complex was isolated only with the most powerful electron-donating solvent HMPTA $^{21}$.

In complexes such as $\mathrm{Me}_{3} \mathrm{SnX}-\mathrm{D}$ the tin atom is bonded to three electropositive $\left(\mathrm{CH}_{3}\right)$ and two electronegative [ $\mathrm{Hal}\left(\right.$ or $\left.\mathrm{CF}_{3}\right)$ and D] substituents. Therefore on going from $\mathrm{Me}_{3} \mathrm{SnX}$ to $\mathrm{Me}_{3} \mathrm{SnX}-\mathrm{D}$ the relative content of s electrons in the $\mathrm{Sn}-\mathrm{C}-\mathrm{H}$ fragment increases as well as the relative content of $\mathrm{p}$ electrons in the $\mathrm{Sn}-\mathrm{X}$ bonds. For complexes such as $\mathrm{Me}_{3} \mathrm{SnHal}-\mathrm{D}$ the above-mentioned model is confirmed by n.m.r. (Table 6) and n.q.r. ${ }^{54}$ data: for complexes of the type $\mathrm{Me}_{3} \mathrm{SnCF}_{3}-\mathrm{D}$ this is borne out by the results of the $J\left({ }^{1{ }^{19}} \mathrm{Sn}-\mathrm{C}-{ }^{1} \mathrm{H}\right)$ and $J\left({ }^{119} \mathrm{Sn}-\mathrm{C}-{ }^{19} \mathrm{~F}\right)$ study (Table 7 ).

In completing the discussion about the structure and complexation of organotin compounds it is essential to emphasize that the changes of the relative content of $\mathrm{s}$ and $\mathrm{p}$ electrons in bonds of tin to carbon and other substituents occur simultaneously with the changes in the $\mathrm{Sn}-\mathrm{C}-\mathrm{H}$ and $\mathrm{Sn}-\mathrm{C}-\mathrm{F}$ angles. Consequently, the changes in spectral parameters on going from one molecule to another reflect the changes both in electron and spatial parameters of the molecules, i.e. these parameters cannot be considered separately.

\section{MERCURY COMPOUNDS}

The study of ${ }^{199} \mathrm{Hg}$ chemical shifts of organic and inorganic compounds has not been very intensive ${ }^{56-61}$. The latest data available are given in Table 8.

The limited data and the strong dependence of $\delta\left({ }^{199} \mathrm{Hg}\right)$ on the solvent ${ }^{61}$ make the correlation of these data with the electron structure of the compounds difficult. Nevertheless, it is evident ${ }^{58.60}$ that the electronegative groups make a significant paramagnetic contribution to the observed screening constants.

Table $8 . \delta\left({ }^{194} \mathrm{Hg}\right)$ values for some mercury compounds ${ }^{61}$

\begin{tabular}{|c|c|c|}
\hline Compound & Solvent & $\begin{array}{c}\delta\left(^{149} \mathrm{Hg}\right) \\
(\mathrm{ppm})\end{array}$ \\
\hline $\mathrm{Me}_{2} \mathrm{Hg}$ & & 0 \\
\hline $\mathrm{Bu}_{2} \mathrm{Hg}$ & $\mathrm{CCl}_{4}$ & 205 \\
\hline $\mathrm{n}-\mathrm{Pr}_{2} \mathrm{Hg}$ & $\mathrm{CCl}_{4}$ & 210 \\
\hline $\mathrm{Et}_{2} \mathrm{Hg}$ & $\mathrm{CCl}_{4}$ & 304 \\
\hline $\mathrm{i}-\mathrm{Pr}_{2} \mathrm{Hg}$ & $\mathrm{CCl}_{4}$ & 597 \\
\hline$\left(\mathrm{CH}_{2}=(\mathrm{H})_{2} \mathrm{Hg}\right.$ & $\mathrm{CH}_{2} \mathrm{Cl}_{2}$ & 648 \\
\hline$\left(\mathrm{PhCH}_{2}\right)_{2} \mathrm{Hg}$ & $\mathrm{CH}_{2} \mathrm{Cl}_{2}$ & 700 \\
\hline $\mathrm{Ph}_{2} \mathrm{Hg}$ & $\mathrm{CH}_{2} \mathrm{Cl}_{2}$ & 742 \\
\hline$\left(\mathrm{CH}_{3} \mathrm{COOCH}_{2}\right)_{2} \mathrm{Hg}$ & $\mathrm{CH}_{2} \mathrm{Cl}_{2}$ & 769 \\
\hline$\left(\mathrm{CH}_{2}=(\mathrm{Cl})_{2} \mathrm{Hg}\right.$ & $\mathrm{CH}_{2} \mathrm{Cl}_{2}$ & 1149 \\
\hline
\end{tabular}


We will further concentrate our attention on the $J\left({ }^{199} \mathrm{Hg}-\mathrm{C}-{ }^{-1} \mathrm{H}\right), J\left({ }^{199} \mathrm{Hg}-\right.$ $\left.\mathrm{C}-{ }^{19} \mathrm{~F}\right)$ and $J\left({ }^{199} \mathrm{Hg}-{ }^{13} \mathrm{C}\right)$ spin-spin coupling constants, and on their correlations with the structure of organomercury compounds and their complexes. First of all, let us consider the question about the influence of $\mathrm{R}$ and $\mathrm{X}$ in $\mathrm{RHgX}$ on the $J\left({ }^{199} \mathrm{Hg}-\mathrm{C}^{-1} \mathrm{H}\right)$ constants. Some typical data are given in Table 9.

Table 9. $J\left({ }^{199} \mathrm{Hg} \mathrm{C}-^{-1} \mathrm{H}\right)$ constants for $\mathrm{RHgX}$ compounds in $\mathrm{CDCl}_{3}{ }^{62-65}$

\begin{tabular}{|c|c|c|c|c|c|}
\hline$R_{R}$ & $\mathrm{R}$ & 1 & $\mathrm{Br}$ & $\mathrm{Cl}$ & OAc \\
\hline $\begin{array}{l}\mathrm{Me}_{3} \mathrm{CCH}_{2}{ }^{62} \\
\mathrm{Me}^{25,63} \\
\mathrm{CF}_{3} \mathrm{CH}_{2} \mathrm{CH}_{2}{ }^{64} \\
\mathrm{PhCH}_{2}{ }^{65}\end{array}$ & $\begin{array}{r}94.0 \\
104.3 \\
110.4 \\
131.3\end{array}$ & $\begin{array}{l}\overline{192.0} \\
198.0 \\
-\end{array}$ & $\begin{array}{l}192.0 \\
212.0 \\
- \\
252.0\end{array}$ & $\begin{array}{l}193.0 \\
215.0 \\
223.0 \\
263.0\end{array}$ & $\begin{array}{l}204.0 \\
220.0 \\
- \\
264.5\end{array}$ \\
\hline
\end{tabular}

The data of Table 9 show an increase of $J\left({ }^{199} \mathrm{Hg}-\mathrm{C}-{ }^{1} \mathrm{H}\right)$ values with the growth of electron-withdrawing power of the groups $\mathrm{R}$ and $\mathrm{X}$. For compounds of the type $\left(\mathrm{RR}^{\prime} \mathrm{CH}\right)_{2} \mathrm{Hg}^{66}$ and $\mathrm{RCO}_{2} \mathrm{HgCH}_{3}{ }^{67}$ linear dependences of $J\left({ }^{19 y} \mathrm{Hg}-\mathrm{C}-{ }^{1} \mathrm{H}\right)$ with $p K_{\mathrm{a}}$ of $\mathrm{RR}^{\prime} \mathrm{CH}_{2}$ and $\mathrm{RCOOH}$, respectively, were observed. For phenyl ${ }^{68}$ and benzyl ${ }^{69,70}$ derivatives of mercury the regularities in changes of the $J\left({ }^{199} \mathrm{Hg}-{ }^{1} \mathrm{H}\right)$ constants through the 3-7 carbon atoms were traced.

In 1963 Hatton, Schneider and Siebrand ${ }^{71}$ analysed the dependences of $J\left({ }^{199} \mathrm{Hg} \mathrm{C}{ }^{1} \mathrm{H}\right)$ on the nature of $X$ in methyl and ethyl derivatives of mercury and derived the conclusion that the main contribution in the observed constants is made by the Fermi contact coupling. The contribution of spinorbital coupling was estimated as negligible, while the dipole-dipole term was shown to be important in some cases. Recently ${ }^{72}$ an extended Hückel procedure for calculating $J\left({ }^{199} \mathrm{Hg}-\mathrm{C}-{ }^{1} \mathrm{H}\right)$ constants for a variety of methylmercury systems was outlined. This author ${ }^{72}$ concluded that the orbital contraction of the $6 \mathrm{~s}$ orbital of mercury with increasing electronegativity of the substituent $X$ is an important contributing factor to the large range spanned by these coupling constants.

In connection with these conclusions ${ }^{71,72}$ it is very interesting to analyse the results of the $J\left({ }^{199} \mathrm{Hg}-\mathrm{C}-{ }^{19} \mathrm{~F}\right)$ and $J\left({ }^{199} \mathrm{Hg}-{ }^{13} \mathrm{C}\right)$ study. Some of the $J\left({ }^{199} \mathrm{Hg}-\mathrm{C}-{ }^{19} \mathrm{~F}\right)$ values are given in Table 10.

Table 10. $J\left({ }^{199} \mathrm{Hg}-\mathrm{C}-{ }^{19} \mathrm{~F}\right)$ values for $\mathrm{CF}_{3} \mathrm{HgX}$ compounds ${ }^{73-75}$

\begin{tabular}{llc}
\hline \multicolumn{1}{c}{$\mathrm{X}$} & Solvent & $\begin{array}{c}\left.J{ }^{199} \mathrm{Hg} \mathrm{C}-{ }^{19} \mathrm{~F}\right) \\
(\mathrm{Hz})\end{array}$ \\
\hline $\mathrm{CH}_{3}$ & $\mathrm{CH}_{2} \mathrm{Cl}_{2}$ & 932 \\
$\mathrm{C}_{6} \mathrm{H}_{5}$ & $\mathrm{CHCl}_{3}$ & 1008 \\
$\mathrm{CF}_{3}$ & $\mathrm{CHCl}_{3}$ & 1250 \\
$\mathrm{I}$ & $\mathrm{CH}_{2} \mathrm{Cl}_{2}$ & 1710 \\
$\mathrm{Br}$ & $\mathrm{CHCl}_{3}$ & 1800 \\
$\mathrm{Cl}$ & $\mathrm{CHCl}_{3}$ & 1920 \\
$\mathrm{CF}_{3} \mathrm{CO}_{2}$ & $\mathrm{CHCl}_{3}$ & 2208 \\
\hline
\end{tabular}




\section{S. PETROSYAN AND O. A. REUTOV}

It is evident from the data of Table 10 that in this case the $J\left({ }^{199} \mathrm{Hg}-\mathrm{C}-{ }^{19} \mathrm{~F}\right)$ values also increase very sharply with the growth of the electron-withdrawing power of the group $X$, i.e. they manifest the same features as the $J\left({ }^{199} \mathrm{Hg}-\right.$ $\mathrm{C}^{-1} \mathrm{H}$ ) values in relative compounds of the type $\mathrm{CH}_{3} \mathrm{HgX}$. Using the viewpoint already stated in the discussion of $J\left({ }^{119} \mathrm{Sn}-\mathrm{C}-{ }^{1} \mathrm{H}\right)$, we can conclude that in the case of compounds such as $\mathrm{RHgX}$ the growth of electron-withdrawing power of $\mathrm{X}$ results in a redistribution of electrons, so that the relative content of $\mathrm{s}$ electrons increases in the $\mathrm{C}-\mathrm{Hg}$ bonds and the relative content of $\mathrm{p}$ electrons increases in the $\mathrm{Hg}-\mathrm{X}$ bonds. In this case the contraction of the valence $6 \mathrm{~s}$ orbital of mercury is bound to change the valence angles $\mathrm{Hg} \mathrm{C}-\mathrm{H}$ and $\mathrm{Hg}-\mathrm{C}-\mathrm{F}$. Recently $J\left({ }^{199} \mathrm{Hg}-\mathrm{C}-{ }^{19} \mathrm{~F}\right)$ values were obtained for the wide range of fluoroalkyl ${ }^{76-78}$, and earlier for fluorovinyl ${ }^{79}$, and fluorophenyl ${ }^{60}$ derivatives of mercury.

$J\left({ }^{199} \mathrm{Hg}-{ }^{13} \mathrm{C}\right)$ spin-spin coupling constants became available recently ${ }^{37.38 .62,80-82}$ owing to the development of the new technique in n.m.r. spectroscopy. $J\left({ }^{199} \mathrm{Hg}-{ }^{13} \mathrm{C}\right)$ values for compounds of the type $\left(\mathrm{RCH}_{2}\right)_{2} \mathrm{Hg}$ are given in Table 11 .

Table 11. $J\left({ }^{199} \mathrm{Hg}-{ }^{13} \mathrm{C}\right)$ values for $\left(\mathrm{RCH}_{2}\right)_{2} \mathrm{Hg}$ compounds ${ }^{37.38 .62 .82}$

\begin{tabular}{lcc}
\hline \multicolumn{1}{c}{$\mathrm{R}$} & Solvent & $\begin{array}{c}J\left({ }^{199} \mathrm{Hg}_{-}{ }^{13} \mathrm{C}\right) \\
(\mathrm{Hz})\end{array}$ \\
\hdashline $\mathrm{C}_{6} \mathrm{H}_{5}$ & $\mathrm{CHCl}_{3}$ & 631 \\
$\mathrm{CH}_{3}$ & $\mathrm{CHCl}_{3}$ & 648 \\
$\mathrm{CH}_{3} \mathrm{CH}_{2} \mathrm{CH}_{2}$ & - & 656 \\
$\left(\mathrm{CH}_{3}\right)_{3} \mathrm{C}$ & & 684 \\
$\mathrm{H}$ & & 690 \\
$\mathrm{CH}_{3} \mathrm{OCO}$ & $\mathrm{CHCl}_{3}$ & 753 \\
$\mathrm{CF}_{3}$ & $\mathrm{CHCl}_{3}$ & 896 \\
\hline
\end{tabular}

It is evident from the data of Table 11 that $J\left({ }^{199} \mathrm{Hg}^{13} \mathrm{C}\right)$ increases with the growth of the electron-withdrawing power of the group $\mathrm{R}$. An exception in this series is dibenzylmercury: in the opinion of these authors ${ }^{82}$ this can be rationalized by $\sigma-\pi$ conjugation in the $\mathrm{C}_{6} \mathrm{H}_{5}-\mathrm{CH}_{2}-\mathrm{Hg}$ fragment, which was postulated earlier in our laboratory ${ }^{83}$. It is interesting that $J\left({ }^{199} \mathrm{Hg}^{13} \mathrm{C}\right)$ also increases with increasing electron-withdrawing power of $\mathrm{X}$ in compounds of the type $\left(\mathrm{CH}_{3}\right)_{3} \mathrm{CCH}_{2} \mathrm{HgX}^{62}$; the data in Table 12 show this.

Table 12. $J\left({ }^{199} \mathrm{Hg}^{13} \mathrm{C}\right)$ values for $\left(\mathrm{CH}_{3}\right)_{3} \mathrm{CCH}_{2} \mathrm{HgX}$ compounds in $\mathrm{CDCl}_{3}{ }^{62}$

\begin{tabular}{lccc}
\hline $\mathrm{X}$ & $\begin{array}{c}J\left({ }^{199} \mathrm{Hg}^{13} \mathrm{C}\right) \\
(\mathrm{Hz})\end{array}$ & $\begin{array}{c}J\left({ }^{199} \mathrm{Hg}-\mathrm{C}^{1} \mathrm{H}\right) \\
(\mathrm{Hz})\end{array}$ & $\begin{array}{c}J\left({ }^{13} \mathrm{C}-{ }^{1} \mathrm{H}\right) \\
(\mathrm{Hz})\end{array}$ \\
$\mathrm{CH}_{2} \mathrm{C}\left(\mathrm{CH}_{3}\right)_{3}$ & 684 & 94.0 & 126.0 \\
$\mathrm{CH}_{3}$ & 690 & 102.0 & 126.5 \\
$\mathrm{CH}_{2} \mathrm{CH}$ & 820 & 109.0 & 127.5 \\
$\mathrm{CN}$ & 1404 & 173.0 & 135.0 \\
$\mathrm{Cl}$ & 1514 & 193.0 & 138.0 \\
\hline
\end{tabular}


It follows that $J\left({ }^{199} \mathrm{Hg}^{13} \mathrm{C}\right)$ spin-spin coupling constants are affected in compliance with the redistribution of electrons according to Bent, and depend mainly on the relative content of s electrons in the $\mathrm{Hg}-\mathrm{C}$ bonds. It is interesting that changes in $J\left({ }^{199} \mathrm{Hg}-{ }^{13} \mathrm{C}\right)$ for compounds of the type $\left(\mathrm{CH}_{3}\right)_{3} \mathrm{CCH}_{2} \mathrm{HgX}$ are proportional to changes in $J\left({ }^{199} \mathrm{Hg}-\mathrm{C}-{ }^{1} \mathrm{H}\right)$ for the same compounds. In this case only chlorine gives a deviation from the linear dependence of these constants, and this can be rationalized by the (d-p) $\pi$ conjugation of the methylene group and mercury atom ${ }^{62}$. At the same time $J\left({ }^{199} \mathrm{Hg}-\mathrm{C}^{-1} \mathrm{H}\right)$ constants depend linearly on $J\left({ }^{13} \mathrm{C}^{-1} \mathrm{H}\right)$ for the $\mathrm{CH}_{2}$ group. The authors ${ }^{62}$ believe that these data provide evidence for the increase of the $\mathrm{s}$ character of the $\mathrm{sp}^{3}$-hybrid orbitals of methylene carbon in $\mathrm{C}-\mathrm{C}$ and $\mathrm{C}-\mathrm{H}$ bonds, for its decrease in $\mathrm{C}-\mathrm{Hg}$ bonds and for the decrease of the geminal angle $\mathrm{H}-\mathrm{C}-\mathrm{Hg}$ with the growth of the electron-withdrawing power of $\mathrm{X}$.

Thus, $J\left({ }^{199} \mathrm{Hg}-\mathrm{C}-{ }^{1} \mathrm{H}\right), J\left({ }^{199} \mathrm{Hg}-\mathrm{C}-{ }^{19} \mathrm{~F}\right)$ and $J\left({ }^{199} \mathrm{Hg}-{ }^{13} \mathrm{C}\right)$ spin spin coupling constants are extremely sensitive spectral parameters and they give very important information about the electron and spatial structure of organomercury compounds.

The application of n.m.r. spectroscopy of ${ }^{199} \mathrm{Hg}$ to the study of complexation of organomercury molecules in solutions has been successful. First of all, it should be noted that $J\left({ }^{199} \mathrm{Hg}-\mathrm{C}-{ }^{1} \mathrm{H}\right), J\left({ }^{199} \mathrm{Hg} \mathrm{C}-{ }^{19} \mathrm{~F}\right)$ and $J\left({ }^{199} \mathrm{Hg}-\right.$ ${ }^{13} \mathrm{C}$ ) constants are extremely dependent upon the nature of the solvent in which the given organomercury compound is studied (Tables 13-16).

Table 13. The effect of solvents on the $J\left({ }^{199} \mathrm{Hg}-\mathrm{C}-{ }^{1} \mathrm{H}\right)$ in $\left(\mathrm{RCH}_{2}\right)_{2} \mathrm{Hg}$ compounds ${ }^{20.85-87}$

\begin{tabular}{l|rrrrrr}
\hline & $\mathrm{CCl}_{4}$ & $\mathrm{CH}_{2} \mathrm{Cl}_{2}$ & Dioxane & Pyridine & DMFA & DMSO \\
\hline $\mathrm{CH}_{3}{ }^{85}$ & & & & & & \\
$\mathrm{H}^{20}{ }^{8}{ }^{8} \mathrm{H}_{5}{ }^{86.87}$ & 98.0 & 98.0 & 101.0 & 102.0 & 102.5 & 104.5 \\
$\mathrm{CH}_{2}=\mathrm{CH}^{87}$ & 102.0 & 102.0 & 103.0 & 107.5 & 108.5 & 109.5 \\
\hline
\end{tabular}

Table 14. The effect of solvents on the $J\left({ }^{199} \mathrm{Hg}-{ }^{13} \mathrm{C}\right)$ and $J\left({ }^{199} \mathrm{Hg}-\mathrm{C}-{ }^{1} \mathrm{H}\right)$ constants in $\mathrm{Et}_{2} \mathrm{Hg}^{82.85}$

\begin{tabular}{lcc}
\hline Solvent & $\begin{array}{c}J\left({ }^{199} \mathrm{Hg}-{ }^{13} \mathrm{C}\right) \\
(\mathrm{Hz})\end{array}$ & $\begin{array}{c}J\left({ }^{199} \mathrm{Hg}-\mathrm{C}-{ }^{-1} \mathrm{H}\right) \\
(\mathrm{Hz})\end{array}$ \\
$\mathrm{CCl}_{4}{ }_{\mathrm{CHCl}_{3}}$ & 642 & 98.0 \\
$\mathrm{DME}$ & 648 & 98.0 \\
Pyridine & 663 & 101.0 \\
DMSO & 679 & 102.0 \\
& 688 & 104.5 \\
\hline
\end{tabular}

The analysis of the data of Tables 13 and 14 shows that the $J\left({ }^{199} \mathrm{Hg}-\mathrm{C}-{ }^{1} \mathrm{H}\right)$ and $J\left({ }^{199} \mathrm{Hg}^{13} \mathrm{C}\right)$ constants increase with the growth of the electrondonating abilities of the solvents. In this case it is very important for the interpretation of these data that the $J\left({ }^{199} \mathrm{Hg}-\mathrm{C}-\mathrm{C}-{ }^{1} \mathrm{H}\right)$ and $J\left({ }^{199} \mathrm{Hg} \mathrm{C}-{ }^{13} \mathrm{C}\right)$ constants in $\mathrm{Et}_{2} \mathrm{Hg}$ are solvent independent and equal to $127.5^{85}$ and $25^{82} \mathrm{~Hz}$, respectively. We believe that it is this circumstance that gives rise to changes 
in spin-spin coupling constants on complexation and determines the solvation mechanism of organomercury compounds. Taking into account that the main contribution in all the observed heteronuclear spin -spin coupling constants is made by the contact Fermi coupling, specified by the selectron density on the coupled nuclei ${ }^{71}$, it can be suggested that $s$ electron density in a mercury atom does not change on the solvation of organomercury compounds $^{85}$. If this is not the case, the $\beta$ constants of mercury will be affected as well as the corresponding $\alpha$ constants. Therefore, no matter what complex is formed, $\mathrm{R}_{2} \mathrm{Hg}-\mathrm{D}$ or $\mathrm{R}_{2} \mathrm{Hg}-2 \mathrm{D}$, solvation occurs on account of the interaction of the $\mathrm{p}$ electrons of the heteroatom in $\mathrm{D}$ and the low-energy vacant orbitals of mercury. As a result of this interaction an additional electron density is transferred to the organomercury molecule and in the complex formed the redistribution of electrons occurs according to Bent, so that the relative content of the s electron increases in the $\mathrm{Hg}-\mathrm{C}$ bonds and the relative content of $\mathrm{p}$ electrons increases in the $\mathrm{Hg}-\mathrm{D}$ bonds. As for $\beta$ carbon nuclei and more so for $\beta$-hydrogen nuclei, the redistribution seems to be unpropagated to them because of the deterioration of the inductive effect. It is possible that the alternative mechanisms of solvation and changes in spin-spin coupling constants of mercury with the carbon and hydrogen nuclei occur; the effect of solvents on the $J\left({ }^{199} \mathrm{Hg}-\mathrm{C}-{ }^{19} \mathrm{~F}\right)$ is highly contradictary. Thus, with the growth of the electron-donating ability of the solvent these constants increase for $\mathrm{CF}_{3} \mathrm{HgX}$ compounds (Table 16), but decrease for $\mathrm{R}_{2} \mathrm{Hg}$ compounds (Table 15).

Table 15. The effect of solvents on $J\left({ }^{199} \mathrm{Hg}-\mathrm{C}-{ }^{19} \mathrm{~F}\right)$ for $\mathrm{R}_{2} \mathrm{Hg}$ compounds ${ }^{77}$.

\begin{tabular}{l|cccc}
\hline Solvent & $\mathrm{CCl}_{4}$ & $\mathrm{CH}_{2} \mathrm{Cl}_{2}$ & DME & Pyridine \\
\hline $\mathrm{CF}_{3} \mathrm{CF}_{2}$ & & & & \\
$\mathrm{CF}_{3} \mathrm{CFCl}$ & 793 & 787 & 745 & 684 \\
$\left(\mathrm{CF}_{3}\right)_{2} \mathrm{CF}$ & 689 & 680 & 585 & 533 \\
$\mathrm{CF}_{3} \mathrm{CFH}$ & 535 & 507 & 387 & 338 \\
\hline
\end{tabular}

Table 16. The effect of solvents on $J\left({ }^{199} \mathrm{Hg}-\mathrm{C}-{ }^{19} \mathrm{~F}\right)$ for $\mathrm{CF}_{3} \mathrm{HgX}$ compounds ${ }^{75}$

\begin{tabular}{lr|rrrrrr}
\hline $\mathrm{X}$ & Solvent & Benzene & $\mathrm{CH}_{2} \mathrm{Cl}_{2}$ & $\mathrm{THF}$ & Acetone & DMFA & DMSO \\
$\mathrm{I}$ & & & & & & \\
$\mathrm{Cl}$ & 1708 & 1722 & 1752 & 1758 & 1766 & 1766 \\
$\mathrm{CF}_{3} \mathrm{CO}_{2}$ & 1906 & 1922 & 1914 & 1924 & 1934 & 1942 \\
\hline
\end{tabular}

It is interesting that there is an increase of $J\left({ }^{199} \mathrm{Hg} \mathrm{C}-\mathrm{C}-{ }^{19} \mathrm{~F}\right)$ in all molecules under investigation and $J\left({ }^{199} \mathrm{Hg}-\mathrm{C}^{-1} \mathrm{H}\right)$ in $\left(\mathrm{CF}_{3} \mathrm{CFH}\right)_{2} \mathrm{Hg}$. The authors ${ }^{77}$ believe that such an anomaly in the behaviour of $J\left({ }^{199} \mathrm{Hg}-\mathrm{C}-{ }^{19} \mathrm{~F}\right)$ for $\mathrm{R}_{2} \mathrm{Hg}$ is due to the interaction of $\alpha$-fluorine $\mathrm{p}$ electrons with the vacant 
orbitals of the mercury atom. Perhaps this question will be clarified after the study of the solvent effect on $J\left({ }^{199} \mathrm{Hg}-\mathrm{C}-{ }^{19} \mathrm{~F}\right)$ and $J\left({ }^{199} \mathrm{Hg}-\mathrm{C}-{ }^{1} \mathrm{H}\right)$ in $\mathrm{C}_{6} \mathrm{H}_{5} \mathrm{CH}_{2} \mathrm{HgCF}_{3}{ }^{88,89}$, which is underway in our laboratory.

Thus, we conclude that n.m.r. spectroscopy of heavy nuclei is an extremely powerful method of investigation of the structure and complexation of different derivatives of metals. The solving of some important problems in this field, such as the detailed understanding of the contributions in heavy nuclei screening constants, the elucidation of spin-spin coupling constants of these nuclei with other nuclei, and the determination of the signs of $J\left({ }^{119} \mathrm{Sn}-\right.$ $\left.\mathrm{C}-{ }^{19} \mathrm{~F}\right)$ and $J\left({ }^{199} \mathrm{Hg}-\mathrm{C}-{ }^{19} \mathrm{~F}\right)$ constants will allow this method to be used even more productively for obtaining information about the structure and complexation of many inorganic and organometallic compounds.

\section{REFERENCES}

1 V. S. Petrosyan and O. A. Reutov, J. Organomet. Chem.. 52. 307 (1973)

${ }^{2}$ R. G. Kidd. Characterization of Organometallic Compounds. Part II. pp. 373 437. (ed. M. Tsutsui), New York, Wiley (1971).

3 J. J. Burke and P. C. Lauterbur, J. Am. Chem. Soc., 83, 326 (1961).

${ }^{4}$ H. C. Clark. J. T. Kwon, L. W. Reeves and E. J. Wells. (an. J. Chem. 42.941 (1964).

5 W. McFarlane, J. Chem. Soc. A, 1630 (1968).

6 B. K. Hunter and L. W. Reeves, Can. J. Chem., 46, 1399 (1968).

7 A. G. Davies. P. G. Harrison, J. D. Kennedy, T. N. Mitchell. R. J. Puddephat and W. McFarlane. $J$. Chem. Soc., C, 1136 (1969).

${ }^{8}$ E. V. Van den Berghe and G. P. Van der Kelen. J. Organomet. Chem.. 26. 207 (1971).

9 A. G. Davies. L. Smith, P. J. Smith and W. McFarlane. J. Organomet. Chem.. 29. 245 (1971).

10 A. Tupciauskas, N. M. Sergeyev and Yu. A. Ustynyuk, Mol. Phys.. 21, 179 (1971).

11 A. Tupćiauskas. N. M. Sergeyev and Yu. A. Ustynyuk. Org. Magn. Resonance. 3. 655 (1971).

12 A. Tupçiauskas, N. M. Sergeyev and Yu. A. Ustynyuk, Liet. Fiz. Rinkinys. 11.93 (1971).

13 A. Tupćiauskas, V. K. Torocheshnikov, N. M. Sergeyev and Yu. A. Ustynyuk. J. Organomet. Chem., 35. C25 (1972).

14 W. McFarlane and R. J. Wood, J. Organomet. Chem., 40. C17 (1972).

15 L. Ferdonck and G. P. Van der Kelen. J. Organomet. Chem. 40.139 (1972).

16 P. J. Smith, R. F. M. White and L. Smith. J. Organomet. Chem., 40. 341 (1972).

17 W. McFarlane. J. C. Maire and M. Delmas. J. C. S. Dalton. 1862 (1972).

18 A. Tupćiauskas. Annual Review of NMR Spectroscopy. (ed. E. Mooney). submitted for publication.

19 S. Boue, M. Gielen and J. Nasielski, Bull. Soc. Chim. Belges, 76, 559 (1967).

20 V. S. Petrosyan, A. S. Voyakin and O. A. Reutov, Zh. Org. Khim.. 6, 889 (1970).

21 V. S. Petrosyan, A. B. Permin and O. A. Reutov, Izv. Akad. Nauk SSSR. Ser. Khin.. N6 (1974).

22 J. Lorberth and H. Varenkamp, J. Organomet. Chem.., 11, 111 (1968).

${ }^{23}$ N. W. G. Debye, D. E. Fenton, S. E. Ulrich and J. J. Zuckerman. J. Organomet Chem.. 28. 339 (1971).

24 L. A. Fyodorov and E. I. Fedin, Izp. Akad. Nauk SSSR. Ser. Khim.. 787 (1971).

25 G. Barbieri and F. Taddei. J. C. S. Perkin II. 1323. 1327 (1972)

26 J. R. Holmes and H. D. Kaesz. J. Am. Chem. Soc., 83, 3903 (1961).

${ }_{27}$ L. Verdonck and G. P. Van der Kelen. Ber. Bunsenges. Physik. Chem. 69, 478 (1965).

${ }^{28}$ L. Verdonck and G. P. Van der Kelen. Bull. Soc. Chim. Belges. 76, 258 (1967).

${ }^{29}$ L. Verdonck, G. P. Van der Kelen and Z. Eeckhaut. J. Organomet. Chem.. 11. 487 (1968)

${ }^{30}$ L. Verdonck and G. P. Van der Kelen, J. Organomet. Chem.. 11. 491 (1968).

31 M. Gielen. M. R. Barthels, M. de Clercq. C. Dehouck and G. Mayence. J. Organomet. Chem.. 34. 315 (1972)

32 C. E. Holloway, S. A. Kandil and Y. M. Walker. J. Am. Chem. Soc.. 94. 4027 (1972).

${ }^{33}$ H. C. Clark, J. T. Kwon, L. W. Reeves and E. J. Wells, Can. J. Chem., 41, 3005 (1963),

${ }^{34}$ H. C. Clark. N. Cyr and J. H. Tsai Can. I. Chem.. 45, 1073 (1967). 


\section{S. PETROSYAN AND O. A. REUTOV}

35 W. McFarlane. J. Chem. Soc., A, 528 (1967)

${ }^{36}$ H. Dreeskamp and G. Stegmeier. Z. Naturforsch. 22A. 1458 (1967)

${ }^{37}$ F. G. Weigert. M. Winokur and J. D. Roberts. J. Am. Chem. Soc.. 90. $1566(1968)$.

${ }^{38}$ F. G. Weigert and J. D. Roberts. J. Am. Chem. Soc.. 91. 4940 (1969).

39 Yu. K. Grishin, N. M. Sergeyev and Yu. A. Ustynyuk. Org. Mayn. Resonance. 4. 337 (1972).

${ }^{40}$ C. D. Schaeffer and J. J. Zuckerman, J. Organomet. Chem.. 47. Cl (1973).

41 H. A. Bent. Chem. Rev., 61. 275 (1961).

42 N. A. Matviyoff and R. S. Drago. Inorg. Chem., 3. 337 (1964).

${ }^{43}$ E. V. Van den Berghe and G. P. Van der Kelen. Bull. Soc. Chim. Belges. 74. 479 (1965).

${ }^{44}$ W. Kitching. Tetrahedron Letters. 3689 (1966).

45 T. F. Bolles and R. S. Drago, J. Am. Chem. Soc.. 88. 5730 (1966).

46 G. Matsubayashi. Y. Kawasaki. T. Tanaka and R. Okawara Bull. Chem. Soc. Japan. 40. 155 (1967).

47 V. G. K. Das and W. Kitching. J. Organomet. Chem.. 13, 523 (1968).

48 D. G. Hendricker. Inorg. Nucl. Chem. Letters. 5. 115 (1969).

${ }^{49}$ L. A. Fyodorov. D. N. Kravtzov. A. S. Peregudov. E. I. Fedin and E. M. Rochlina. $I z r$ Akad. Nauk SSSR. Ser. Khim., 1705 (1971).

${ }^{50}$ K. Kawakami and T. Tanaka. J. Organomet. Chem.. 49, 409 (1973).

$\$ 1$ V. S. Petrosyan. N. S. Yashina and O. A. Reutov. J Organomet. Chem. 52. 315 (1973).

52 R. Hulme. J. Chem. Soc. 1524 (1963).

53 J. Buckle, P. G. Harrison. T. J. King and J. A. Richards. J. C. S. Chem. Commun. 1104 (1972).

${ }^{54}$ V. S. Petrosyan. N. S. Yashina, O. A. Reutov, E. V. Bryuchova and G. K. Semin. J. Organomet. Chem.. 52, 321 (1973).

55 V. S. Petrosyan, N. S. Yashina, V. I. Bakhmutov, A. B. Permin and O. A. Reutov, J. Organomet. Chem., in the press (1974).

56 R. E. Dessy. T. J. Flautt. H. H. Jaffe and G. F. Reynolds. J. Chem. Phys.. 30. 1422 (1959).

${ }^{57}$ S. S. Dharmatti. C. R. Kanekar and S. C. Mathur. Proc. Symp. Chem. Coord. Comp.. p. 152. Agra. India (1959).

58 W. G. Schneider and A. D. Buckingham, Discussions Faraday Suc.. 34. 147 (1962),

${ }^{59}$ P. D. Godfrey, M. L. Hefferman and D. F. Kerr, Austral. J. Chem., 17, 701 (1964).

60 W. McFarlane, J. Chem. Soc., A, 2280 (1968).

${ }^{61}$ A. Tupciauskas. N. M. Sergeyev, Yu. A. Ustynyuk and A. N. Kashin. J. Maun. Resonuice. 7. 124 (1972).

62 G. Singh and G. S. Reddy. J. Organomet. Chem., 42. 267 (1972).

63 P. R. Wells and W. Kitching. Tetrahedron Lelters, 1531 (1963).

64 A. K. Prokofyev and O. Yu Ochlobystin, Dokl. Akad. Nauk SSSR. 204. 1371 (1972).

65 L. A. Fyodorov. E. I. Fedin. B. A. Kvasov and I. P. Beletskaya. Zh. Strukt. Khim. 10. 247 (1969).

${ }^{66}$ I. P. Beletskaya. E. I. Fedin. L. A. Fyodorov. B. A. Kvasov and O. A. Reutov. Izt. Akad. Nauk SSSR, Ser. Khim., 221 (1967).

67 D. F. Evans, P. M. Ridout and Y. Warf, J. Chem. Soc., A. 2127 (1968).

68 V. S. Petrosyan and O. A. Reutov, Izv. Akad. Nauk SSSR, Ser. Khim.. 1962 (1968).

69 V. S. Petrosyan, V. I. Rozenberg. Yu G: Bundel' and O. A. Reutov. Izr. Akad. Nauk SSSR. Ser. Khim., 1958 (1968).

${ }_{70}$ V. S. Petrosyan and O. A. Reutov, Izv. Akad. Nauk SSSR. Ser. Khim.. 1403 (1970).

71 J. W. Hatton, W. G. Schneider and W. Siebrand, J. Chem. Phys.. 39. 1330 (1963).

${ }^{72}$ H. F. Henneike, J. Am. Chem. Soc, 94. 5945 (1972).

${ }^{73}$ M. D. Rausch and J. R. Van Wazer, Inorg. Chem., 3. 761 (1964).

74 D. Seyferth. S. P. Hopper and G. J. Murphy. J. Organomet. Chem., 46, 201 (1972)

75 V. S. Petrosyan. V. I Bakhmutov and O. A. Reutov, J. Organomet. (hem.. in the press (1974).

76 V. R. Polischuk, L. S. German and I. L. Knunyantz, Izv. Akad. Nauk SSSR. Ser. Khim., 620 , 795, 2024 (1971).

${ }^{77}$ L. A. Fyodorov. Z. A. Stumbrevichute. B. L. Dyatkin. B. I. Martynov and S. R. Sterlin. Dokl. Akad. Nauk SSSR. 204. 1135 (1972).

78 L. M. Iagupol'skii, V. I. Popov, N. V. Kondratenko and E. V. Konovalov, Zh. Org. Khim., 10, 277 (1974).

79 T. D. Coyle, S. L. Stafford and F. G. A. Stone, Spectrochim. Acta. 17. 968 (1961)

80 K. A. McLauchlan. D. H. Whiffen and L. W. Reeves. Mol. Phys.. 10. 131 (1966).

81 P. R. Dean and W. McFarlane, Mol. Phys. 13. 343 (1967). 
${ }^{82}$ L. A. Fyodorov, Z. A. Stumbrevichute, A. K. Prokofyev and E. I. Fedin, Dokl. Akad. Nauk SSSR, 209, 134 (1973).

83 Yu. G. Bundel', N. D. Antonova and O. A. Reutov, Dokl. Akad. Nauk SSSR, 166. 1103 (1966).

84 V. S. Petrosyan and O. A. Reutov, Dokl. Akad. Nauk SSSR. 180. 876 (1968).

85 V. S. Petrosyan, N. S. Yashima and O. A. Reutov, Izv. Akad. Nauk SSSR, Ser. Khim., 1018 (1972).

${ }^{86}$ I. P. Beletskaya E. I. Fedin, L. A. Fyodorov, B. A. Kvasov and O. A. Reutov. Dokl. Akad. Nauk SSSR, 174, 354 (1967).

87 L. A. Fyodorov and E. I. Fedin, Dokl. Akad. Nauk SSSR, 195, 856 (1970).

${ }^{88}$ V. S. Petrosyan, S. M. Sakembayeva, V. I. Bachmutov and O. A. Reutov, Dokl. Akad. Nauk SSSR, 209, 1117 (1973).

89 V. S. Petrosyan, V. I. Bakhmutov and O. A. Reutov, Izv. Akad. Nauk. SSSR, Ser. Khim., N6 (1974). 